\title{
The issue of equivalence in English and Uzbek proverbs
}

\author{
Bozorova Viloyat Muzaffarovna', Maqsudova Mokhigul Usmonovna ${ }^{2}$ \\ Teachers of ESP for Humanitarian Subjects \\ Foreign Languages Faculty \\ Bukhara State University
}

\begin{abstract}
It is difficult to compare the peoples of Central Asia with the peoples of Europe. They have no nationality, no way of life, no beliefs, no language. In general, it is impossible to compare the peoples of the world who live far away from each other. In particular, the Uzbek people have almost nothing to do with the British people.

Key words: proverb, phraseological point of view, equivalent compounds, equivalents of phrases.
\end{abstract}

\section{I.Introduction}

There is almost no record of the British in our history. Even today, no matter how much people try to get closer, the imagination of an ordinary Uzbek young man about the British people is very shallow. The British are a completely different world; we are a completely different world.

Those who read one or two letters of English will understand how far apart the two languages are. It is very easy to translate almost all sentences from English to Russian. All you have to do is know the translation of the words, and it will find its place. Because both of English and Russian belong to the Indo-European language family. The structure of speech in Uzbek is the exact opposite of that in other languages. Because our language belongs to the Altaic language family. Therefore, an artist who decides to translate from English must first be a master of the Uzbek language.

\section{II.Literature review}

From a phraseological point of view, it is very difficult for us to translate English proverbs, sayings and idioms. The structure of English proverbs is very different from ours. The biggest difference is that the rhyme, verse, tone in English proverbs is not so strong. What you want to say is just what you want to say. A similar sentence can be used in everyday conversation. When you read it, it doesn't sound as beautiful, as melodic, and as poetic as our proverbs. For example,

- $\quad$ First catch your hare and then cook it

Avval quyoningni tutib ol, keyin qovur

- $\quad$ A small leak will sink a great ship

Arzimagan suv tomchisi katta kemani cho 'ktiradi

- $\quad$ Respect yourself, or no one else will respect you

$O$ 'zingni hurmat qil, bo 'lmasa hech kim seni hurmat qilmaydi

The interest in the English language in our country has been growing for many years. The majorities of young people today want to learn English and are more literate. Learning English is not an easy task for us Uzbeks. That's why many people prefer to learn English through Russian. There are many similarities between Russian and English because they belong to the same family. There is little or no connection between Uzbek and English. Anyone who has ever tried to learn a language understands this.

\section{III.Analysis}

There is a concept of "alternative" in our language, which is derived from Arabic. In the past, the word "equivalent" was used instead. With the advent of the Uzbek-Russian dictionary in 1959, the term "alternative", which was forgotten in our language, became actively used in scientific methods. However, the words "equivalent" and "alternative" have often been used interchangeably.

Well-known translator Gaybulla Salomov writes: "In two languages, without context, we have accepted proverbs, sayings and idioms that have similar meanings and can replace each other as 'equivalent compounds'."

Examples of equivalent compounds are:

Easy to say - Aytishga oson, Like mother, like daughter. - Onasini ko 'rib, qizini ol, Money begets money - Pul pulni topar and others.

Usually, not only the meaning but also the form and even the objects of the equivalent compounds match.

However, there are so many proverbs, parables and idiomatic expressions in English that Uzbeks do not always 
have their exact equivalents. That is why we call phraseologies whose meanings can only replace each other in a certain context. Sometimes a Russian compound can have more than one compound in the same context. Such combinations are called "alternative options".

While the alternatives or alternatives of a compound can only replace each other within the context, their forms, and especially their objects, often do not match, even if their meanings are correct.

The interpreter decides which alternative phrase to choose depending on the process of events described in the play, the situation, the nature of the image, and other circumstances. That's why there are so many differences between translators when it comes to choosing alternatives. Equivalents of some phrases may be an alternative to other combinations.

Thus, the difficulty of translating from one language to another, especially poetic translation, the incompatibility of some formal elements in languages, the meaning expressed in certain languages by specific categories can be expressed in another language in the same way. Cases such as overestimation of some formal element have led some scholars to conclude that it is not possible to translate from one language to another at all.

Some proverbs, in particular idioms, could not be translated verbatim from one language to another, leading them to this conclusion. Indeed, to prove on the basis of translations from English into Uzbek that phraseological expressions are not a unit that cannot be translated from one language to another is that such a "theory" is unfounded and futile. Clearly shows that it is possible to translate.

Are there equivalents in Uzbek and English articles? A number of Uzbek researchers seeking to answer this question have done a number of good things in recent years. In 2000, Karomatkhon Karomatova and Hamidulla Karomatov published a large collection of equivalent articles in Uzbek, Russian, and English. Simply titled "Proverbs Proverbs - Proverbs", the book is arranged in alphabetical order, trying to cover as much as possible all aspects of life. Each English proverb is first translated into Uzbek and then into Uzbek and Russian. The collection was edited by Gaybulla Salomov, a pioneer of translation studies and a great translator of proverbs. The book may be the teacher's last contribution to translation studies. In any case, it is safe to say that the book has given a new impetus to Uzbek translation and enriched our vocabulary.

No matter how much a book is recognized as a novelty in translation studies and in our literature in general, it is full of mistakes and shortcomings. First of all, it is surprising that the structure of English proverbs has been distorted in it for incomprehensible reasons. For example,

- $\quad$ Absent is always in the wrong, the;

- $\quad$ Fat is in the fire, the;

- Hard nut to crack, $a$;

- Leave in the lurch, to.

It makes no sense in these articles to use the articles $a$ and the at the end of a sentence. The auxiliary verb, to does not correspond to English grammar either. It's easy to see why they're being misused. Presumably, the publisher made a mistake in publishing the book. Anyway, at least I didn't go down without explaining myself first.

In the same year, the Gafur Ghulam Publishing House of Literature and Art published a small dictionary of English-Uzbek proverbs and sayings. The collection, written by Sharof Mirzo, contains 266 English proverbs and alternative phrases. The collection contains the most popular, widespread and widely used English folk proverbs. Its articles can be found in many other collections. The success of this publication is that it has chosen an alternative to those popular English articles from the well-known Uzbek folk proverbs.

The Karakalpak and Uzbek peoples have lived side by side, neighbors and relatives for centuries. Their language is not far from ours. Karakalpak language also belongs to the family of Turkic languages. But that doesn't mean two nations are one nation. They have their own nationality, their own folklore and their own proverbs. Gulsha Musaeva, a Karakalpak girl studying at Karakalpak State University in 2003, read English, Karakalpak, Uzbek and Russian proverbs, sayings and idioms in her first book, The Karakalpak, Uzbek and Russian Equivalents of English Proverbs adapted to continuous alternatives. To be able to analyze 400 phraseologies, it is necessary to know the nationalities and peculiarities of the four peoples.

\section{IV.Discussion}

The study of English and scientific analysis have developed in our country since independence. The number of scientific works, PhD dissertations, and even doctoral dissertations in English linguistics has increased in recent years. It is not difficult to find a source for English phraseology. First of all, the translation of English articles into Russian, their equivalents, articles on English phraseology, in general, do not pose a big problem for those who want to study English folklore.

However, there are many unresolved issues in the study of the direct connection of Uzbek folklore with British folklore, in the comparison of the products of these two peoples. Uzbek linguist Khantora Yusupov tried to open one of these doors. The book, titled Uzbek Folk Proverbs, translates Uzbek folk proverbs and sayings into English. The 
equivalent of existing phraseology is also presented. The translation of Uzbek articles into English has become a great innovation in our linguistics. No translator had dared to do so before. If you look at the contents of the forthcoming book, you will see that the articles are divided into groups according to their content and spirit. A number of groups, such as right and wrong, oppression and inequality, peace and tranquility, can find Uzbek articles on any topic and use their English translation. The book is about to be published. We are confident that this collection will be one of the greatest achievements in translation and lexicography in recent years.

According to Western scholars, in every color we see, we can see the nationality of a people. In general, nationality is reflected not only in colors, but in all aspects of our lives. There is no doubt that nationalism has a high place in folklore.

Not all of us pay attention to the plane crashes that have become a daily topic of news programs in recent years. As you can see, the first thing that comes to mind is the "black box" of crashed planes. This is because it contains all the information about the aircraft. It is unknown at this time what he will do after leaving the post. Now, let's think about the similarities between the black box of an airplane and folk sayings.

Proverbs, as we have said, contain the history, origins, and other valuable information of each nation. There is a saying among the Uzbek people, "Close the oven when it's hot." The proverb teaches us to do everything on time. The same is true of the saying, "Press the iron in the heat." If you pay attention, you will see that the proverb is unique to the peoples of Central Asia. After all, the tandir exists only in our countries. Things that do the same thing may exist in other nations. But it's not called a tandir, and it doesn't look like us. The "black box" of the proverb is hidden in this oven.

Karomatkhon Karomatova and Hamidulla Karomatov used the phrase

- $\quad$ All are not saint that go to the church

in their collections. A direct translation of a proverb in the form of

- $\quad$ Cherkovga borganlarning hammasi ham avliyo bo 'lavermaydi

This proverb is very specific to Christian nations. Because the church is basically a Western concept. Of course, the fact that we have the word "church" in our language shows that we have the same concept. But we know the church only as a temple of the Western peoples, and the word "church" came into our language from the Russian word "serkov."

Translators as equivalent to this article

- $\quad$ Eshak Makkaga borgani bilan hoji bo 'lmas

quotes the proverb. The alternative has been very successful. Because the content of the proverb has been revealed, and the methodology has been preserved without deviating from the religious theme.

- All bread is not baked in one oven

The proverb is translated into Uzbek as follows.

- $\quad$ Hamma non ham bitta tandirda yopilgan emas

The word "Oven" translates as tandir. In fact, the tandir is something foreign to the British. Because they don't have an oven. In them, bread is baked in ovens. The dictionary translation of "Oven" is the pech. To the proverb

- Har supraning noni bor

phraseology was chosen as the equivalent.

It should be noted that the semantic features of English proverbs differ from other peoples in their originality. This, of course, was greatly influenced by the religion, culture, and way of life of the people. It is not clear to us who of the proverbs in the vernacular are most widely used in his speech, while others are shortened and, moreover, completely lost.

\section{V.Conclusion}

In short, each nation has its own national spirit, mentality and characteristics, and these characteristics also affect the literature, traditions and folklore of these peoples. In the process of finding alternatives between English and Uzbek proverbs, we came across the fact that in some places it is not possible to translate words correctly just by translating them verbatim. In some cases, it is necessary to analyze the spirituality of the people, to feel their psyche and to connect them to the mentality. Despite the fact that it has been studied by various scholars, it is natural that new ideas and opinions emerge in finding the equivalence of English and Uzbek proverbs. It depends on the field of thinking, worldview, life experience, knowledge and skills of the translator or scientist.

\section{References:}

\# Arora, S. The Perception of Proverbiality. De Proverbio. 1984. - 244p.

* Broukal M., Pineiro C. Grammar. Form and Function. N1. McGraw-Hill. - New-York.: 2004. - 416 p.

* Broukal M., Pineiro C. Grammar. Form and Function. N2. McGraw-Hill. - New-York.: 2004. - 265 p.

* Broukal M., Pineiro C. Grammar. Form and Function. N3. McGraw-Hill. New-York.: 2004. - 385 p.

* Fries Ch. The Structure of English. An Introduction to the Construction of English Sentences. - London.: Longman, 1963.-385p 
\# Honeck, R. A proverb in mind: the cognitive science of proverbial wit and wisdom. - USA.: Lawrence Erlbaum, 1997. - 277p.

* Salomov G'. Language and translation. T .: Fan Publishing House. 1966. 267p.

* Karamatova K.M., Karamatov H.S. Proverbs-Maqollar- Пословицы. - Т.: Mehnat, -2000. -398 b.

\# Imamov K., Mirzayev T., Sarimsakov B., Safarov O. Oral poetry of the Uzbek people. -T .: Teacher, 1990. $303 p$.

* Korunets I.V. Theory and Practice of Translating. - Vinnytsia: Nova Knyga, 2001. -265p.

* Marvin, D.E. Antiquity of Proverbs. - New York and London: G.P Putnam Sons, 1922. -103 p.

\# Madayev O., Sobitova T. Folk oral poetic creativity. - T .: Sharq, 2010. -

* Meider, W. Dundes, A. The Wisdom of Many: Essays on the Proverb. - NewYork: Garland, 1995. -340 p.

\# Mirzaev T., Musokulov A., Sarimsakov B. Uzbek folk proverbs. - T .: Sharq, 2005. -508 p.

\# Mollanazar, H. Principles and methodology of translation. - Tehran: SAMT, 2001.-215p.

* Khudayberganova, G. N. (2019). АНАЛИЗ ФЕНОМЕНА АСКЕТИЗМА В УЧЕНИЯХ МИРОВЫХ РЕЛИГИЙ. Theoretical \& Applied Science, (12), 579-582.

* Alimova, M., \& Nigmatullayev, I. (2019). CLARIFICATION OF TOLERANCE IN ISLAMIC SOURCES. The Light of Islam, 2019(1), 13.

* Alimova, M. (2019). ACTUAL DEVELOPMENT TRENDS OF RELIGIOUS STUDIES IN UZBEKISTAN. The Light of Islam, 2019(4), 42. 